\title{
Rancang Bangun Sistem Informasi Online Registrasi Mahasiswa Baru di Universitas Nahdlatul Ulama Blitar dengan Model Waterfall
}

\author{
Iza Arfiana Fauziah ${ }^{1, *}$, Yeni Ratih Pratiwi ${ }^{2}$, Fatra Nonggala Putra ${ }^{3}$, Abd. Charis Fauzan ${ }^{4}$ \\ Program Studi Ilmu Komputer, Universitas Nahdlatul Ulama Blitar, Indonesia \\ 1izaarfiana@gmail.com; ${ }^{2}$ yeniratih@ @unublitar.ac.id; ${ }^{3}$ fatranp@ unublitar.ac.id; ${ }^{4}$ abdcharis@ unublitar.ac.id \\ * corresponding author
}

INFO ARTIKEL

Sejarah Artikel

Diterima: 20 Juli 2020

Direvisi: 5 Agustus 2020

Diterbitkan: 30 Agustus 2020

Kata Kunci

Model Waterfall

Sistem Informasi Online

Registrasi Mahasiswa Baru

\section{ABSTRAK}

Perkembangan teknologi pada era globalisasi saat ini tidak dapat dihindari, dengan kemajuan yang semakin pesat menjadikan teknologi sebagai media informasi yang sangat dibutuhkan dalam kehidupan. Penelitian ini bertujuan untuk menghasilkan Sistem Informasi Online Registrasi Mahasiswa Baru Universitas Nahdlatul Ulama Blitar berbasis Web dengan PHP dan SQL yang mengelola pelaksanaan pengumpulan berkas mahasiswa baru ke kampus. Jenis penilitian ini adalah Research and Development. Metode pengembangan software menggunakan Waterfall Model. Pengujian perangkat lunak dilakukan melalui pengujian blackbox, serta untuk menggunakan Faktor Kualitas McCall sebagai indikator untuk menentukan tingkat kelayakan perangkat lunak dengan skala pengukuran menggunakan Skala Likert. Hasil penelitian menunjukkan bahwa Sisten Informasi Online Registrasi Mahasiswa Baru berbasis Web dengan PHP dan SQL ini mampu mengelola pelaksanaan pengumpulan berkas mahasiswa baru ke kampus. Penilaian oleh mahasiswa dan admin menunjukkan bahwa perangkat lunak ini sangat layak dari segi usability dan layak dari segi fungsionalitas.

\section{PENDAHULUAN}

Dalam kehidupan sehari-hari sering dijumpai dengan namanya antrian. Salah satu faktor penyebabnya adalah karena jumlah pengunjung dan server (petugas pelayanan) yang tidak seimbang. Contoh antrian yang terjadi seperti antrian nasabah di bank, antrian masyarakat membayar pajak di kantor pajak, antrian konsumen dalam mengisi bahan bakar minyak, antrian konsumen di warung makan, antrian mahasiswa dalam proses administrasi kuliah, dan lain sebagainya. Dari sudut pandang konsumen, jika terdapat pilihan lebih baik mengantri atau tidak mengantri, tentu pilihan yang akan dipilih adalah tidak mengantri, sehingga keperluannya akan cepat terselesaikan tanpa harus berlama-lama menunggu.

Teori antrian pertama kali ditemukan oleh A.K Erlang seorang ahli matematika Denmark pada tahun 1910. Antrian terbentuk jika banyaknya pelanggan yang akan dilayani melebihi kapasitas layanan yang tersedia, sehingga terjadi situasi dimana pelanggan harus antri untuk mendapatkan suatu layanan [1]. Proses antrian merupakan contoh nyata proses Poisson yang banyak terjadi pada berbagai fasilitas pelayanan. Proses antrian merupakan suatu proses yang berhubungan dengan kedatangan pelanggan pada suatu fasilitas pelayanan, menunggu dalam baris antrian jika belum dapat dilayani, kemudian seorang pelanggan akan meninggalkan sarana pelayanan tersebut setelah selesai pelayanan [2]. Analisis di dalam teori antrian dapat dilakukan dengan cara mengambil data waktu kedatangan, waktu pelayanan dan waktu keluarnya pelanggan dari sebuah kegiatan operasional, waktu yang diambil dalam satuan jam, menit dan detik untuk setiap kegiatan, kemudian melakukan 
analisis yang meliputi pengujian distribusi data, menetukan banyak kedatangan pelanggan persatuan waktu, menentukan banyak [3]. Proses antrian berhubungan dengan kedatangan pelanggan pada fasilitas pelayanan, waktu antrian dan meninggalkan fasilitas tersebut. Antrian bisa terjadi karena faktor kurangnya kecepatan pelayanan server (petugas pelayanan), atau juga bisa terjadi karena faktor jumlah server yang melayani tidak memadai [6]. Antrian yang terjadi dapat diminimalisir dengan dilakukannya penganalisaan terhadap kondisi antrian dengan metode Teori Antrian, kemudian diambil tindakan untuk mengatasi masalah antrian tersebut [7][8].

Universitas Nahdlatul Ulama Blitar merupakan universitas yang semakin maju dengan pesat dari tahun berdiri sampai sekarang. Ada banyak mahasiswa yang mendaftar di kampus tersebut. Sehingga ada akibatnya terjadi antrian pada bagian BAAUK (Biro Akademik, Umum dan Kemahasiswaan). Antrian terjadi karena kebutuhan pelayanan melebihi kemampuan pelayanan sehingga pengguna pelayanan tidak mendapatkan pelayanan. Sistem antrian yang tidak efisien menyebabkan pengguna layanan meninggalkan antrian dan kembali di hari yang lain. Hal ini berdampak pada ketidakpuasan dan kekecewaan pengguna layanan yaitu para mahasiswa. Dari latar belakang tersebut penulis tertarik untuk membuat sistem informasi registrasi online mahasiswa baru. Aplikasi ini diharapkan dapat membantu mahasiswa baru dalam melakukan pendaftaran registrasi dapat dilakukan secara online melalui internet.

\section{METODE}

Metode penelitian yang ingin dirancang tersebut pertama yang dilakukan adalah pengumpulan data berdasarkan kebutuhan sistem dari universitas yang diteliti. berikutnya penulis mencari solusi berdasarkan studi data yang dilakukan untuk merangkum semua solusi dan mencari solusi yang paling cocok dalam kondisi yang dihadapi sebagaimana ditunjukkan oleh Gambar 1.

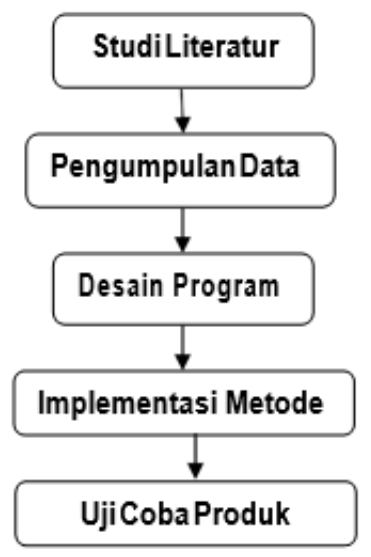

Gambar 1. Metode Penelitian

\section{Studi Literatur}

Metode ini digunakan dengan mengumpulkan data dan informasi dari berbagai sumber bacaan seperti paper, jurnal, artikel dan bacaan-bacaan terkait untuk mendukung proses penulisan kode program maupun dalam penyusunan laporan akhir. 


\section{Pengumpulan Data}

Teknik pengumpulan data yang digunakan adalah sebagai berikut :

1) Wawancara. Metode ini dilakukan dengan mengajukan beberapa pertanyaan kepada karyawan bagian BAAUK (Biro Akademik, Umum dan Kemahasiswaan) yang berkaitan dengan :

a. Apakah sudah menerapkan sistem/aplikasi registrasi online di kampus yang sudah ada?

b. Bagaimanakah aplikasi/sistem tersebut sudah efisien ?

c. Jam pelayanan di BAAUK pukul berapa?

d. Hari Pelayanan di BAAUK hari apa saja ?

e. Apakah biasanya terjadi antrian pengumpulan berkas tidak hanya mahasiswa baru, mahasiswa yang memiliki beasiswa apa juga perlu mengumpulkan berkas ?

f. Untuk satu jam biasanya pelayanan dapat menangani berapa mahasiswa ?

2) Observasi. Pengamatan secara langsung dilakukan dengan mengamati dan mempelajari sistem registrasi online mahasiswa baru yang sudah ada untuk mendapatkan aspek apa saja yang dijadikan landasan dalam menentukan fungsi dari sistem registrasi online yang efisien.

\section{Instrumen Penilaian}

Skala Likert digunakan untuk mengukur sikap, pendapat, dan persepsi dari seseorang atau kelompok orang tentang fenomena sosial [4]. Untuk setiap pilihan jawaban diberi skor, maka responden harus menggambarkan, mendukung pernyataan. Untuk digunakan jawaban yang dipilih. Dengan Skala Likert, maka variabel yang akan diukur dijabarkan menjadi indikator variabel. Kemudian indikator tersebut dijadikan sebagai titik tolak ukur untuk menyusun item-item instrumen yang dapat pertanyaan atau pernyataan. Pada ujung sebelah kanan (angka rendah) menggabarkan suatu jawaban yang besifat negatif, sedangkan ujung sebelah kiri (angka tinggi). Menggambarkan suatu jawaban yang bersifat positif. Skala Likert dirancang untuk menyakinkan responden dalam menjawab berbagai tingkatan pada tiap butir-butir pertanyaan atau pernyataan yang ada dalam kuesioner. Data-data dari variabel yang akan dievaluasi pada penelitian ini akan ditujukan kepada responden menggunakan skala 1-5 untuk mendapatkan data yang sifatnya ordinal maka diberikan skor sebagai berikut:

\begin{tabular}{|l|l|l|l|l|l|}
\hline PK & SB & B & CB & KB & SKB \\
\hline NILAI & 5 & 4 & 3 & 2 & 1 \\
\hline
\end{tabular}

Keterangan:

$\begin{array}{ll}\mathrm{PK} & =\text { Pertanyaaan Kuesioner } \\ \mathrm{SB} & =\text { Sangat Baik } \\ \mathrm{B} & =\text { Baik } \\ \mathrm{CB} & =\text { Cukup Baik } \\ \mathrm{KB} & =\text { Kurang Baik } \\ \mathrm{SKB} & =\text { Sangat Kurang Baik }\end{array}$


Tabel 2. Parameter Bobot Nilai

\begin{tabular}{|c|c|}
\hline Bobot Nilai & Keterangan \\
\hline $0 \%-19,9 \%$ & Sangat Tidak Baik \\
\hline $20 \%-39 \%$ & Kurang Baik \\
\hline $40 \%-59 \%$ & Cukup Baik \\
\hline $60 \%-79 \%$ & Baik \\
\hline $80 \%-100 \%$ & Sangat Baik \\
\hline
\end{tabular}

\section{Teknik Analisis Data}

Teknik analisis data menggunakan deskriptif kuantitatif yaitu memaparkan produk hasil rekayasa perangkat lunak dan menguji tingkat kelayakan produk.

$$
\text { Persentase }=\frac{\text { Nisai yang didapat }}{\text { Nisai NakciNaS }} \times 100 \%
$$

Selanjutnya, dari lima kategori dibuat skala menurut Suharsimi Arikunto, pembagian skala ini hanya dengan memperhatikan rentangan bilangan [5]. Kondisi maksimal yang diharapkan adalah 100\%. Antara 1\% sampai dengan $100 \%$ dibagi rata sehingga menghasilkan kategori kelayakan seperti berikut:

Tabel 3. Skor kelayakan

\begin{tabular}{|l|l|l|}
\hline No. & \multicolumn{1}{|c|}{ Kategori } & Skor dalam Persentase \\
\hline 1. & Sangat Layak & $81 \%-100 \%$ \\
\hline 2. & Layak & $61 \%-80 \%$ \\
\hline 3. & Cukup Layak & $41 \%-60 \%$ \\
\hline 4. & Tidak Layak & $21 \%-40 \%$ \\
\hline 5. & $\begin{array}{l}\text { Sangat Tidak } \\
\text { Layak }\end{array}$ & $<21 \%$ \\
\hline
\end{tabular}

\section{Metode Pengembangan Perangkat}

Pengembangan perangkat lunak menggunakan metode pengembangan waterfall model. Dalam waterfall model terdapat beberapa tahapan utama yang menggambarkan aktivitas pengembangan perangkat lunak sebagaimana ditampilkan pada Gambar 2.

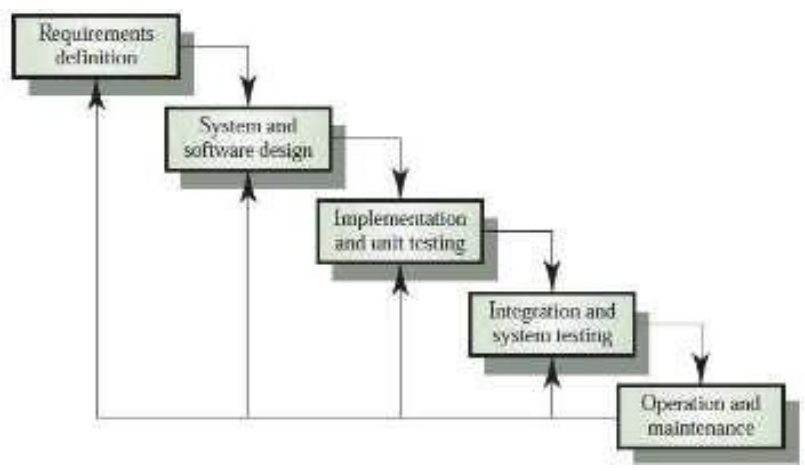

Gambar 2. Model Waterfall 
1. Analisis Kebutuhan. Pada tahap ini dilakukan pengumpulan kebutuhan secara lengkap kemudian dianalisis dan didefinisikan kebutuhan yang harus dipenuhi oleh program yang akan dibangun

2. Desain Sistem. Desain dikerjakan setelah kebutuhan selesai dikumpulkan scara lengkap.

3. Implementasi. Desain program diterjemahkan ke dalam kode-kode dengan menggunakan bahasa pemrograman yang sudah ditentukan. Program yang dibangun langsung diuji secara unit.

4. Pengujian Sistem. Unit-unit program disatukan secara utuh kemudian diuji secara keseluruhan

5. Pemeliharaan. Pemeliharaan dapat berupa penyesuaian atau perubahan karena adaptasi dengan situasi sebenarnya.

\section{Analisis Kebutuhan Sistem}

Perangkat keras yang digunakan untuk mengembangkan Sistem Registrasi Berbasis

Web dengan PHP dan SQL sebagai berikut:

1. Perangkat Server
a. Seperangkat Laptop dengan spesifikasi Processor Intel Core Duo T6600 $2.20 \mathrm{GHz}$
b. RAM $1 \mathrm{~Gb}$
c. VGA Intel GMA $512 \mathrm{Mb}$
d. Monitor/LCD
e. Mouse dan Keyboard

2. Perangkat Client
a. Seperangkat Laptop dengan spesifikasi Processor Intel Core 2 Duo T6600 2.20GHz
b. RAM $1 \mathrm{~Gb}$
c. VGA Intel GMA $512 \mathrm{Mb}$
d. Monitor/LCD
e. Mouse dan Keyboard

3. Perangkat Lunak. Perangkat lunak yang dibutuhkan untuk mengembangkan Sistem Registrasi Online Berbasis Web dengan PHP dan SQL adalah sebagai berikut:
a. Sistem Operasi Windows 7
b. Xampp Server v3.0.12, digunakan SQL server.
c. Adobe Dreamweaver CS5, digunakan untuk pengkodean sistem.
d. Web Browser : Mozilla Firefox, Google Chrome, Opera, dan sejenisnya.

4. Prosedur. Prosedur yang dilakukan oleh Sistem Registrasi Online Berbasis Web adalah sebagai berikut:
a. Login Sistem
b. Pendaftaran Peserta mahasiswa
c. Pengolahan data sekolah asal
d. Pengolahan data alamat domisili
e. Pengolahan data No.hp peserta
f. Pengolahan data Email

5. Pengguna (user). Sistem Registrasi Online terbagi atas 3 pengguna yaitu :

a. User Mahasiswa. Pengguna jenis ini terdiri dari peserta/mahasiswa, wali mahasiswa yang akan melihat jadwal pengumpulan berkas.

b. Administrator. Tipe pengguna hanya diperuntukan staff/panitia yang bertanggungjawab dalam mengelola data peserta. 
c. Super Administrator. Tipe pengguna ini terdiri dari staff kemahasiswaan yang bertanggungjawab mengelola kebutuhan sistem dan administrator, data user, sekolah asal, kecamatan, dan seperti menambahkan administrator.

6. Database. Yang digunakan pada sistem ini adalah SQL. Database ini dipilih karena terbukti populer dan handal dalam menangani sistem berbasis web. Selain itu, database ini juga mampu terintregasi dengan baik dengan bahasa pemrograman PHP.

7. Jaringan komputer. Sistem informasi ini dibangun berbasiskan client-server. Pengguna dapat mengakses sistem ini melalui jaringan internet yang terhubung pada komputer.

\section{Desain Program}

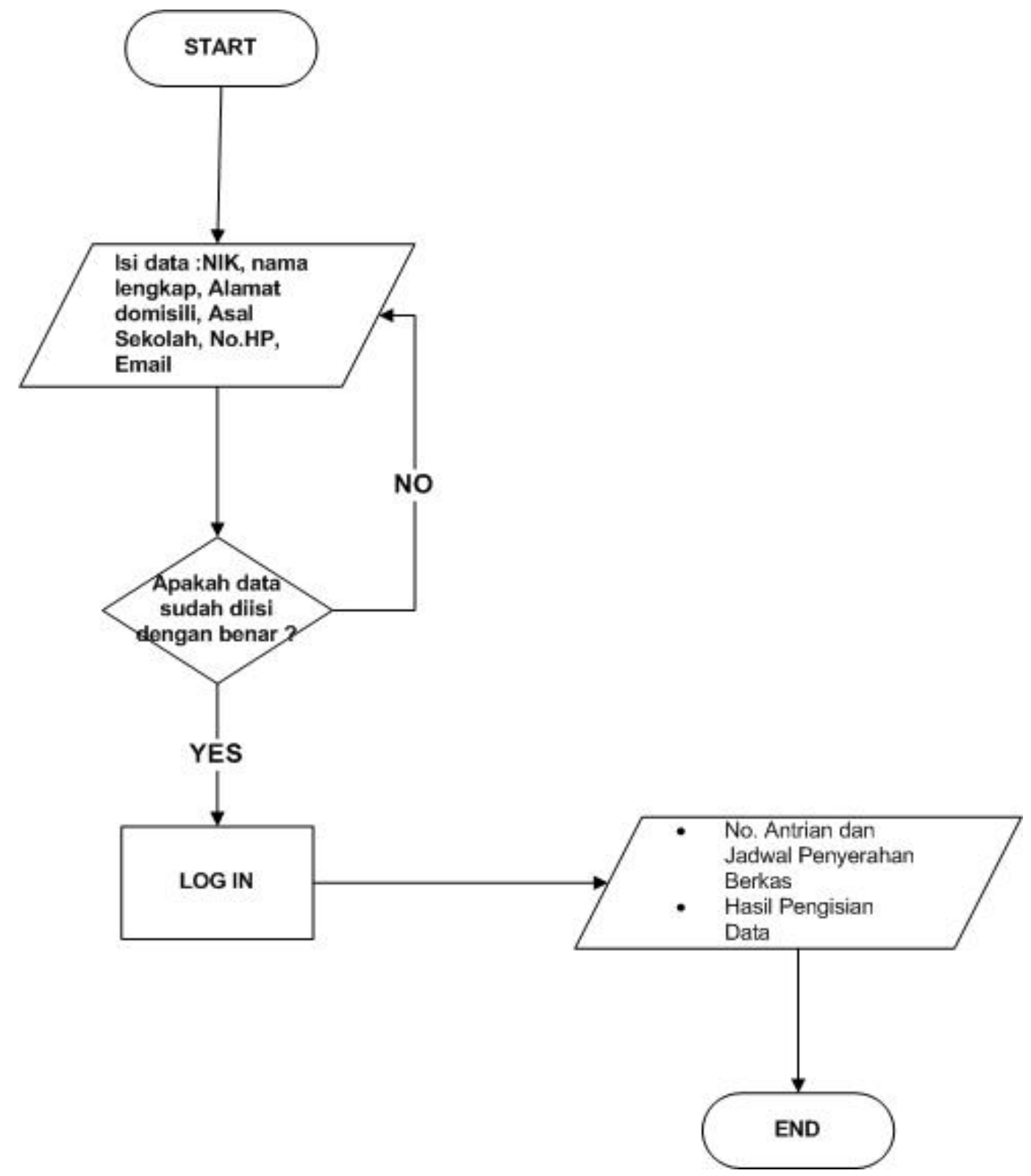

Gambar 3. Flowchart User Mahasiswa 


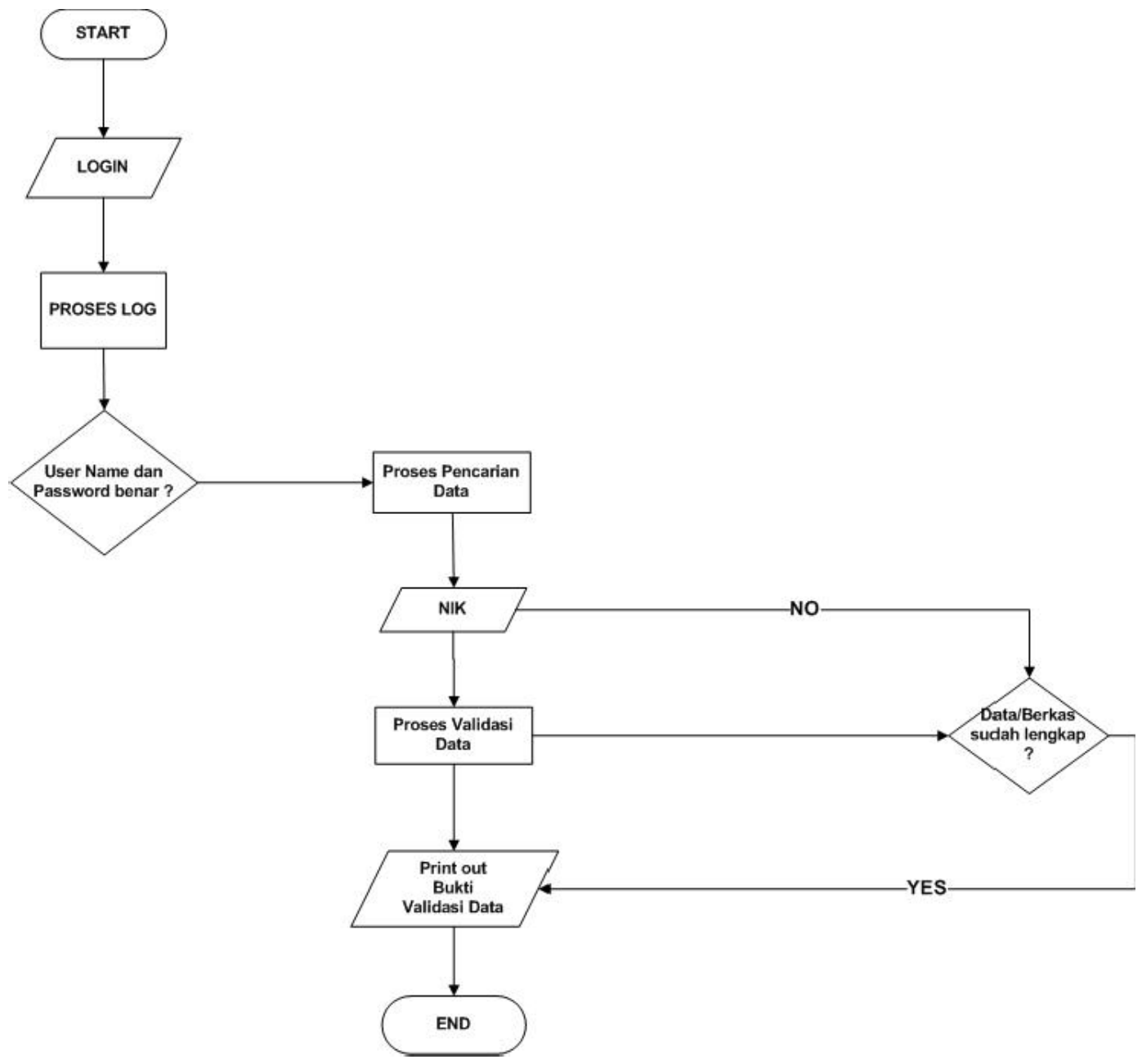

Gambar 4. Flowchart User Admin

\section{Desain Database}

Tabel 4. Desain Database

\begin{tabular}{|l|l|l|}
\hline \multicolumn{3}{|c|}{ tbl_admin } \\
\hline id_adm & int(2) & Auto Increment \\
\hline nama & $\operatorname{varchar(40)}$ & \\
\hline username & varchar(15) & \\
\hline password & varchar(40) & \\
\hline
\end{tabular}

\begin{tabular}{|l|l|}
\hline \multicolumn{2}{|c|}{ tbl_data } \\
\hline nik & char(20) \\
\hline kk & char(8) \\
\hline akte & char(8) \\
\hline ijasah & char(8) \\
\hline admin & int(2) \\
\hline
\end{tabular}

\begin{tabular}{|l|l|l|}
\hline \multicolumn{3}{|c|}{ tbl_maba } \\
\hline nik & char(20) & Primary Key \\
\hline nm_lengkap & varchar(50) & \\
\hline alamat & text & \\
\hline domisili & varchar(20) & \\
\hline asal_sekolar & varchar(40) & \\
\hline hp & char(15) & \\
\hline email & text & \\
\hline
\end{tabular}

\begin{tabular}{|l|l|l|l|}
\hline \multicolumn{4}{|c|}{ tbl_antrian } \\
\hline no & int(3) & Auto Incremen & Primary Key \\
\hline nik & char(20) & & \\
\hline no_antrian & char(3) & & \\
\hline tgl & date & & \\
\hline jam & time & & \\
\hline
\end{tabular}




\section{Pengujian Sistem}

Menurut Roger S. Pressman Pengujian perangkat lunak adalah elemen kritis dari jaminan kualitas perangkat lunak dan mempresentasikan kajian pokok dari spesifikasi, desain dan pengkodean (Roger S., 2002). Pengujian perangkat lunak Sistem Registrasi Online Berbasis Web ini dilakukan sebagai pengujian Black-box. Semua produk yang direkayasa (dan sebagian besar hal lain) dapat diuji dengan cara mengetahui fungsi yang ditentukan dimana produk dirancang untuk melakukannya, pengujian dapat dilakukan untuk memperlihatkan bahwa masing-masing fungsi beroperasi sepenuhnya, pada waktu yang sama mencari kesalahan pada setiap fungsi (Pressman, 2002). Dalam penelitian ini dilakukan melalui pengujian Black-box dilakukan melalui fungsi-fungsi yang ada pada Sistem Registrasi Online.

\section{HASIL}

Sistem Informasi Registrasi Online Mahasiswa Baru berbasis Web dibuat dengan menggunakan bahasa pemrograman PHP dan database SQL. Berdasarkan penggunanya, Sistem Informasi Registrasi Online ini terdiri dari tiga menu utama, yaitu menu user mahasiswa, menu administrator dan menu super administrator.

a. Menu User Mahasiswa. Menu user mahasiswa merupakan menu yang dapat diakses oleh semua pengguna. Menu ini terdiri dari:

1. Input/Isi Form Mahasiswa. Halaman Input data/ Isi form merupakan halaman awal, mengisi data seperti nama, alamat, no.hp, asal sekolah untuk mendapatkan nomer antrian atau jadwal pengumpulan berkas.

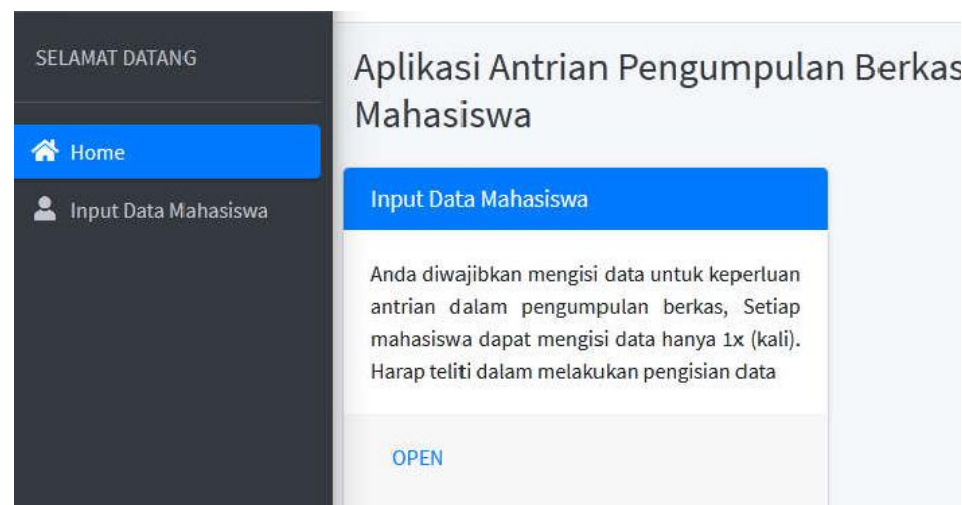

Gambar 5. Halaman Awal untuk user Mahasiswa

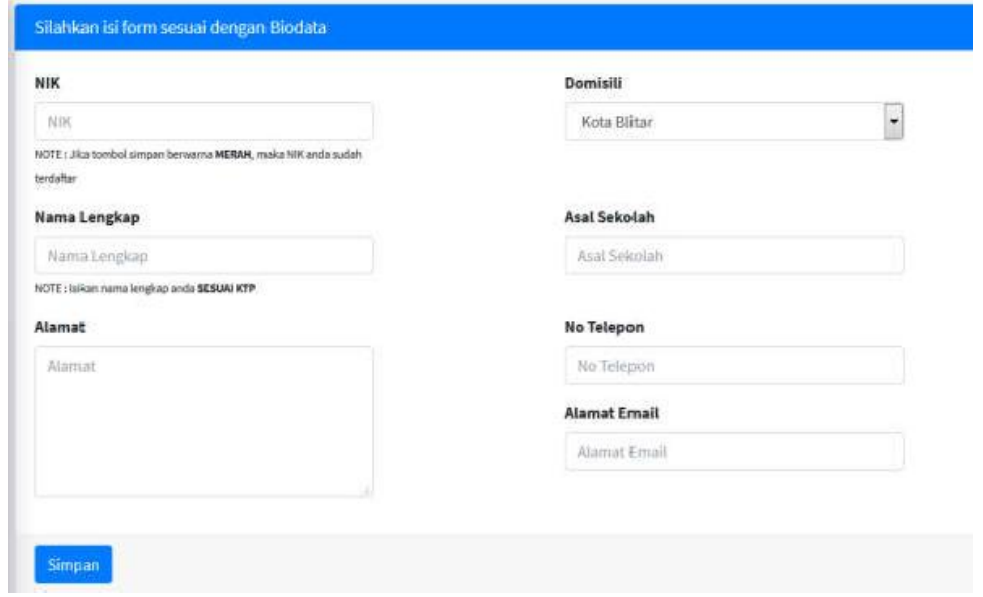

Gambar 6. Halaman Isi Form untuk mahasiswa 
2. Save File. Tools ini berfungsi setelah mahasiswa mengisi data dan akan ada pilihan untuk menyimpan file ini jika tidak mencetak file pdf tersebut.

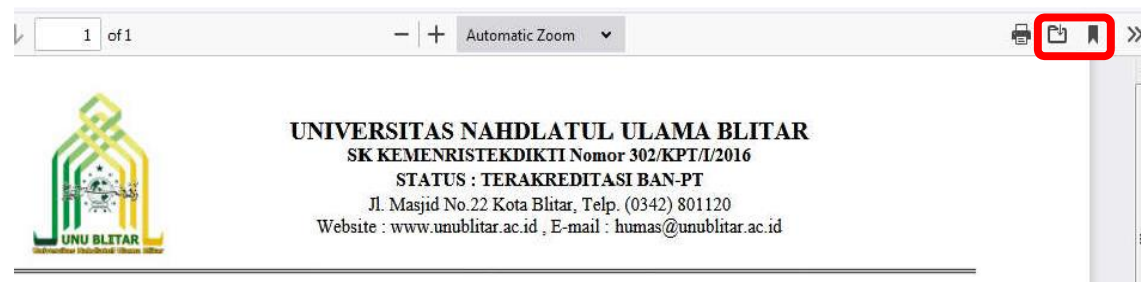

Gambar 7. Tampilan Berkas yang siap di Save

3. Print File. Tools ini berada bersebelahan dengan tools save file, jika ingin langsung mencetak file pdf ini bisa menggunakan tombol ini.

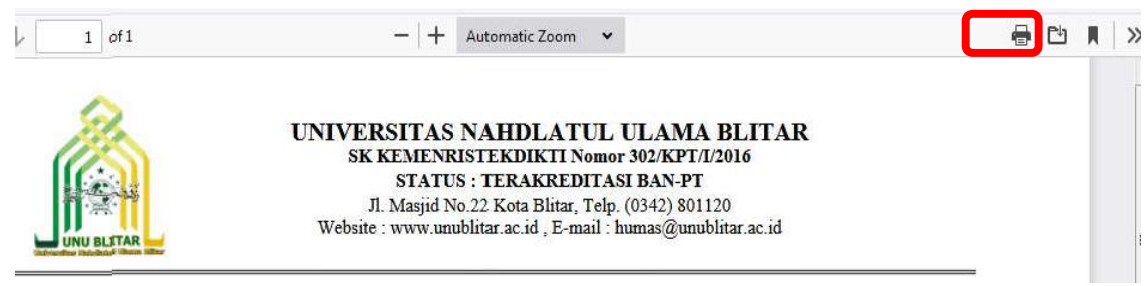

Gambar 8. Tampilan Berkas yang siap di Print

4. Tampilan dari print out dan save as file terdapat nomer antrian yang sudah tertera
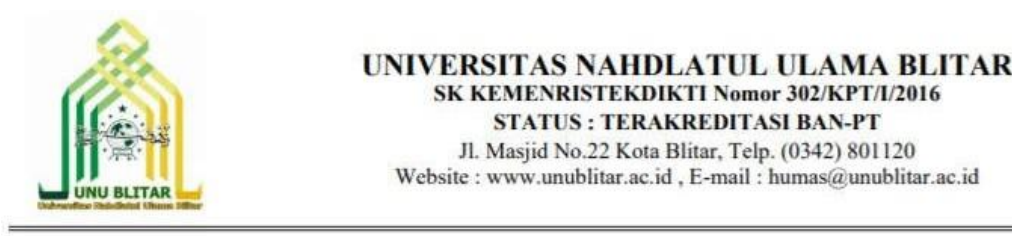

$\begin{array}{lcl}\text { NIK } & : & 123 \\ \text { Nama } & : & \text { AGUS SETIABUDI } \\ \text { Alamat } & : & \text { JALAN MAHAKAM } \\ \text { Domisili } & : & \text { Kota Blitar } \\ \text { Asal Sekolah } & \text { SMKN } 1 \text { BLITAR } \\ \text { No Telp. } & : & 124234234 \\ \text { Email } & : & \text { sdfsdf@gmail.com }\end{array}$

BIODATA

Jadwal Antrian Anda dalam menyerahkan berkas (FC AKTA,FC KK, dan FC IJASAH)

Tanggal : 08 November 2020

Jam : 07:00:00 sampai 08:00:00 WIB 
b. Menu User Administrator. Menu Administrator hanya dapat diakses oleh user Administrator. Menu ini terdiri dari :

1. Halaman Data Mahasiswa. Halaman Data Mahasiswa Baru berfungsi untuk menampilkan data mahasiswa yang mendaftar untuk menyerahkan berkas. Pada halaman ini terdapat tombol "view" berfungsi untuk mengecek data mahasiswa dan berkas apakah sudah seusuai dengan identitas mahasiswa, jika sudah lengkap berkas centang box nama berkas yang sudah tersedia.
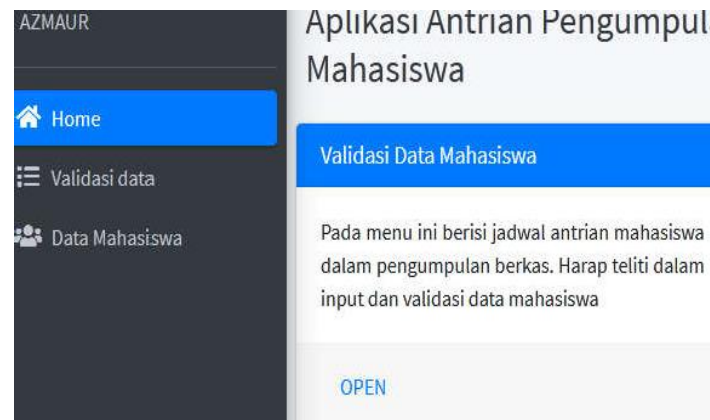

Pada menu ini berisi jadwal antrian mahasiswa dalam pengumpulan berkas. Harap teliti dalam input dan validasi data mahasiswa

OPEN

\section{Database Mahasiswa}

Semua data mahasiswa yg telah mendaftar berada di halaman menu ini,

OPEN

Gambar 10. Tampilan Awal dari menu user Administrator

Aplikasi Antrian Pengumpulan Berkas

Mahasiswa

Data Mahasiswa

\begin{tabular}{|c|c|c|c|c|c|c|}
\hline \multicolumn{4}{|c|}{ Show $10=$ entries } & \multicolumn{3}{|c|}{ Search: } \\
\hline No * & NIK & Mama & ASAL SEKOLAH & Nо НP & BERKAS & Toots \\
\hline 1 & 1655201008 & VIVIAN & SMK 1 NGLEGOK & 085706663275 & BELUM LENGKAP & VIEW $\mid E$ \\
\hline
\end{tabular}

Gambar 11. Tampilan Data Mahasiswa yang sudah masuk

2. Halaman Cetak Bukti Penyerahan Berkas. Halaman ini berfungsi untuk menampilkan Kartu Pendaftaran sebagai bukti telah melakukan pendaftaran. Pada halaman ini admin sudah mengecek semua data dan berkas, jika belum lengkap maka tidak perlu mencetak bukti ini.

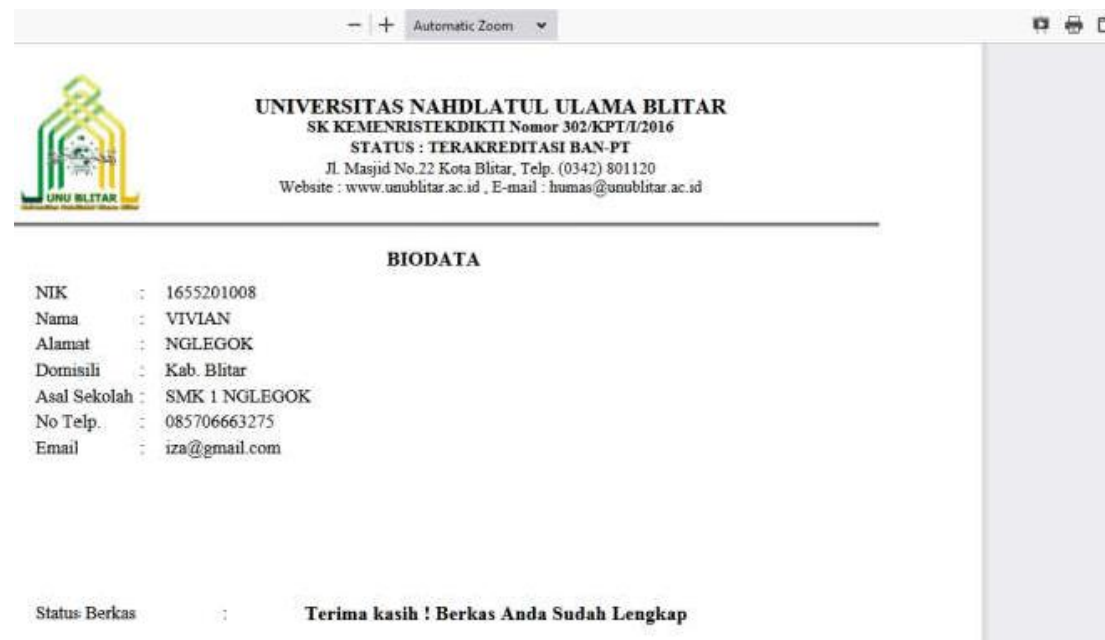

Gambar 12. Tampilan Berkas Mahasiswa bukti pengumpulan berkas lengkap 
3. Tools Pencarian Data Mahasiswa. Tools Pencarian ini berfungsi untuk melakukan pencarian mahasiswa baru berdasarkan kriteria dan kata kunci dari data yang akan dicari.

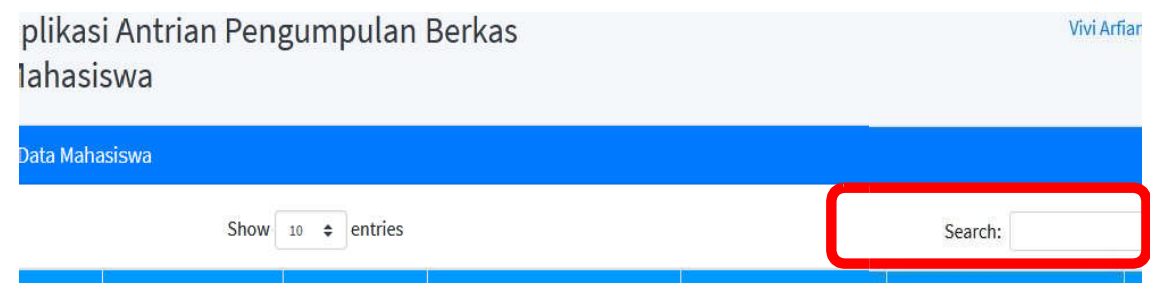

Gambar 13. Tampilan Tools Pencarian Mahasiswa

4. Halaman Validasi Data. Melihat data mahasiswa yang mendaftar pada hari itu dan ditampilkan pembagian jadwalnya. Dan harus dilakukan validasi untuk langkah selanjutnya.

\section{Data Mahasiswa}

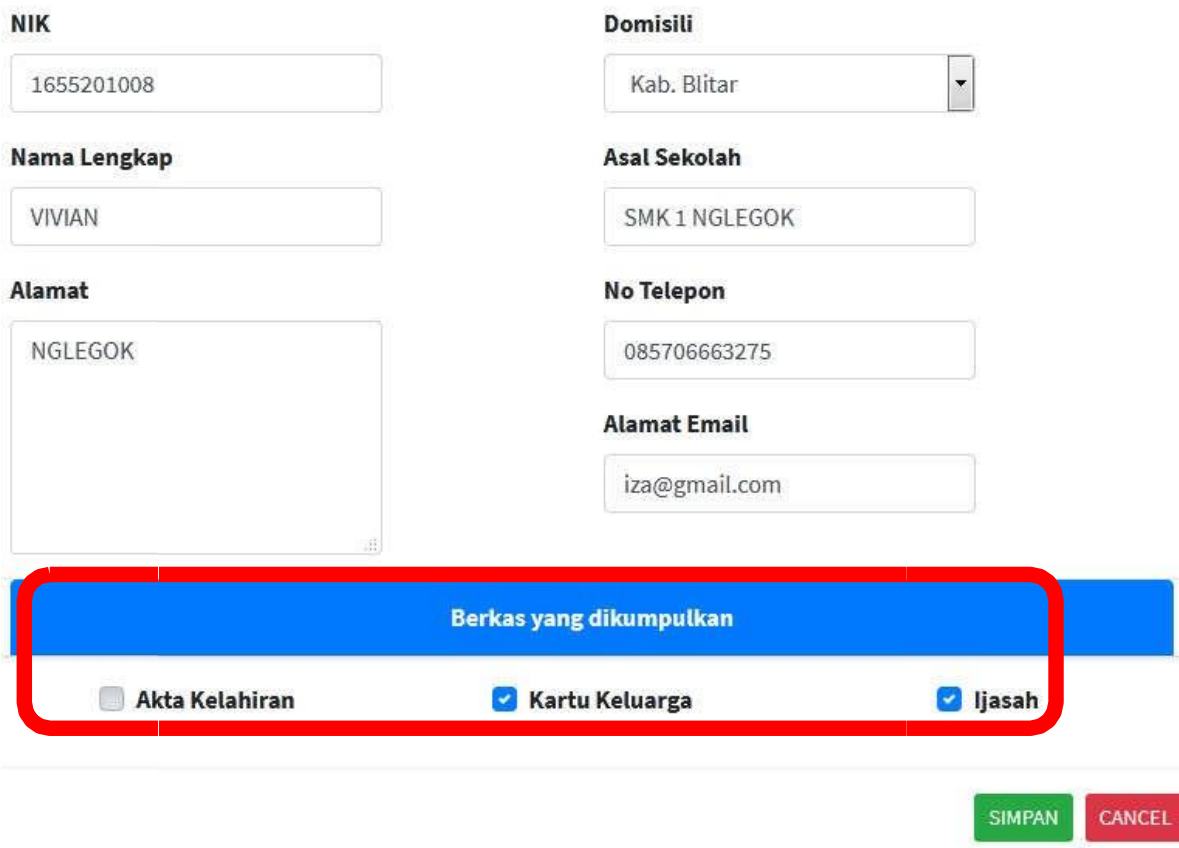

Gambar 14. Tampilan Halaman Validasi Berkas Mahasiswa

c. Menu Super Administrator. Menu Super Administrator hanya dapat diakses oleh user Super Administrator. Menu ini terdiri dari :

1. Halaman Data User Admin. Halaman Data User Admin berfungsi untuk menampilkan data user admin dan melakukan pengolahan data admin, yaitu membuat user admin baru, mengedit dan menghapus data user. Untuk menambah user baru dilakukan dengan meng-klik tombol +admin. 


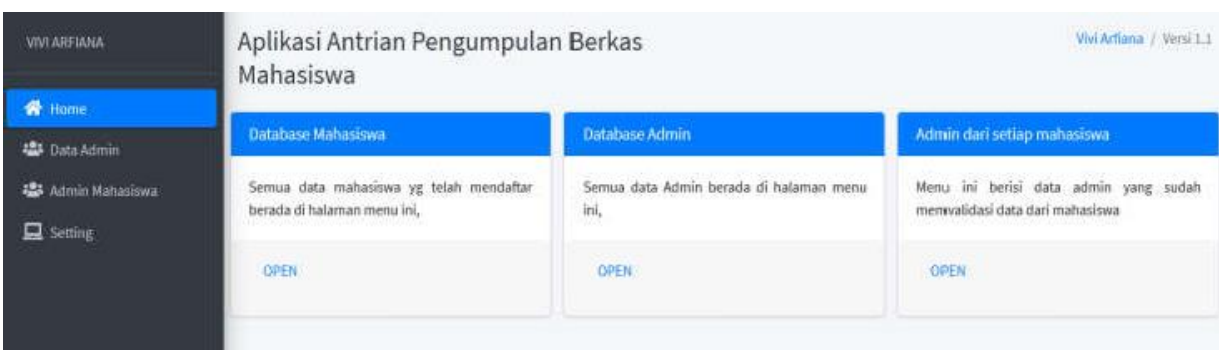

Gambar 15. Halaman Awal User Super Administrator

2. Halaman Setting.

Halaman setting berfungsi untuk mengatur tanggal pengumpulan berkas dan mengatur jumlah mengumpulkan berkas per harinya.

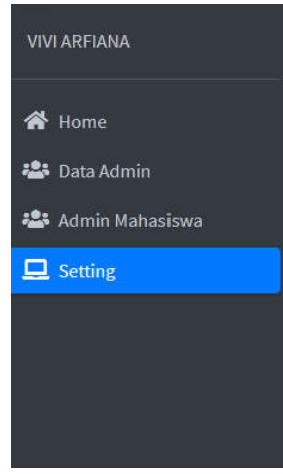

Aplikasi Antrian Pengumpulan Berkas Mahasiswa

Tanggal Mulai Pengumpulan Berkas

Date:

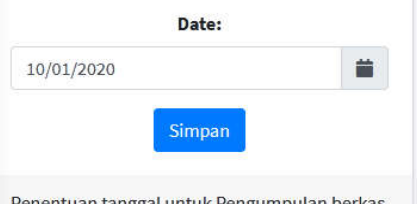

Penentuan tanggal untuk Pengumpulan berkas

hanya bisa dilakukan satu kali

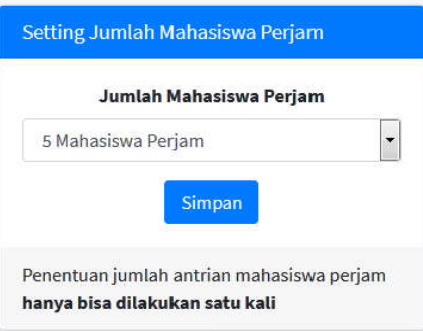

hanya bisa dilakukan satu kali

Gambar 16. Tampilan Halaman Setting

d. Halaman Admin Mahasiswa. Halaman yang berfungsi untuk melihat data sudah divalidasi oleh Admin.
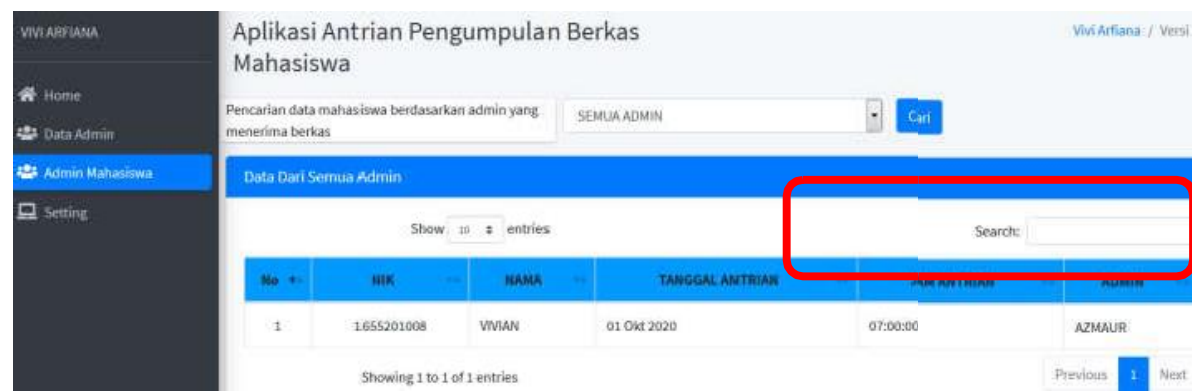

Gambar 17. Tampilan Halaman Admin Mahasiswa

\section{PEMBAHASAN}

Perangkat lunak yang selesai dibuat selanjutnya diuji keseluruhan fungsi- fungsi dan prosedur yang terdapat dalam perangkat lunak tersebut. Pengujian ini dilakukan untuk memastikan bahwa perangkat lunak benar-benar siap untuk diuji cobakan kepada pengguna. Data penilitian diperoleh melalui pemberian seperangkat instrumen atau angket mengenai kelayakan perangkat lunak kepada sejumlah responden. Sebelumnya, masing-masing responden diberi kesempatan untuk mengoperasikan perangkat lunak untuk selanjutnya memberi penilaian terhadap aspek-aspek yang ada dalam perangkat lunak tersebut. Data penelitian ini digunakan untuk menentukan tingkat kelayakan perangkat lunak Sistem Informasi Registrasi Online. Adapun responden yang dilibatkan sebanyak 11 orang yang 
terdiri dari 1 admin yang mewakili pengguna terampil dan 10 orang mahasiswa mewakili pengguna awam. Setelah terkumpulnya jawaban dari responden maka kemudian dihitung semua nilai untuk mendapatkan hasil dari rekapitulasi jawaban responden untuk mendapatkan nilai total dan rata-rata.

Tabel 4. Hasil Persentase Usability

\begin{tabular}{|l|l|l|}
\hline No. & Nama & \multicolumn{1}{|c|}{ Usability } \\
\hline 1 & Jefri & $88 \%$ \\
\hline 2 & Wasimin & $85,3 \%$ \\
\hline 3 & Fuad & $82,6 \%$ \\
\hline 4 & Edi & $84 \%$ \\
\hline 5 & Burhan & $86,6 \%$ \\
\hline 6 & Septi & $82,6 \%$ \\
\hline 7 & Ardi & $81,3 \%$ \\
\hline 8 & Arjuna & $80 \%$ \\
\hline 9 & Anas & $81,3 \%$ \\
\hline 10 & Muid & $86,6 \%$ \\
\hline 11 & Azmaur & $85,3 \%$ \\
\hline
\end{tabular}

Setelah didapatkan nilai rata-rata persentase dari setiap variabel usability dan fungsionalitas kemudian ditotalkan dan dihitung menggunakan rumus yang dijelaskan pada bab sebelumnya, maka dari gabungan semua variabel penulis mendapatkan nilai 83,9 \% yang berarti menunjukan bahwa sebagian besar dari pengguna menyatakan bahwa Sistem Informasi Registrasi Online Mahasiswa Baru layak bagi penggunanya.

\section{KESIMPULAN}

Berdasarkan hasil penelitian dan pembahasan, maka kesimpulan yang dapat diambil dari penelitian ini adalah Perangkat lunak Sistem Informasi Registrasi Online Berbasis Web ini telah berhasil dikembangkan. Sistem ini mampu mengelola antrian yang terjadi di pelaksanaan Penerimaan Mahasiswa baru yaitu penyerahan berkas pendaftaran ke pihak kampus. Berdasarkan penilaian kelayakan perangkat lunak oleh ahli, tingkat kelayakan Sistem Informasi Registrasi Online Berbasis Web dari segi Usability adalah sebesar 83,9 $\%$ (layak), dari segi Fungsionalitas adalah Accepted (layak),. Sedangkan berdasarkan penilaian kelayakan perangkat lunak oleh pengguna, dapat disimpulkan sebanyak 10 mahasiswa dan 1 admin Universitas menyatakan bahwa Sistem Informasi Registrasi Online Berbasis Web layak dari segi usability dan fungsionalitas.

\section{REFERENSI}

[1] Bronson, Richard. "Teori dan Soal-Soal Operation Research." PT Gelora Aksara Pratama (1991).

[2] Taha, Hamdy A. "Riset Operasi Suatu Pengantar." Alih Bahasa oleh Daniel Wirajaya. Binarupa Aksara, Jakarta (1996).

[3] Ayu, Dhea Sekar, and Hetty Krisnani. "Pengaruh Lingkungan Kerja Sehingga Menghasilkan Suatu 
Hubungan Yang Erat Antar Petugas K3L Unpad." Focus: Jurnal Pekerjaan Sosial 1.2 (2018): 16-26.

[4] Rukajat, Ajat. Pendekatan Penelitian Kualitatif (Qualitative Research Approach). Deepublish, 2018.

[5] Suharsimi, Arikunto. "metodelogi Penelitian." Yogyakarta: Bina Aksara (2006).

[6] Waluyo, Bagus, and Fatra Nonggala Putra. "The Effectiveness of Summarizing NLP and Manual Reading Skill in Teaching Reading Comprehension to The Third Semester Students in University of Nahdlatul Ulama Blitar." Journal of Development Research 4.1 (2020): 47-52.

[7] Putra, Fatra Nonggala, and Iza Arfiana Fauziah. "Pemetaan Lokasi Kejadian dalam Sistem Deteksi Kejadian dengan Data Twitter Menggunakan Teori Graf." Briliant: Jurnal Riset dan Konseptual 5.2 (2020): 431-441.

[8] Najah, Shofiyatun, et al. "User Interface (UI) Discovery Application To Measure Query Accuracy On Interface Repository." Journal Of Development Research 3.1 (2019): 1-6. 